\title{
Correlation Analysis Between SoccerGame World Ranking and Player League Distribution
}

\author{
Sandgren Evelina, Karlsson Mia, Ji-Guo Yu* \\ Sports Medicine Unit, Department of Surgical and Perioperative Sciences, Umea University, 90187 Umea, Sweden \\ *Corresponding author: jiguo.yu@idrott.umu.se
}

Copyright $@ 2013$ Horizon Research Publishing All rights reserved.

\begin{abstract}
Nowadays professional soccer player trading between clubs/leagues is very common. Soccer players could be employed in foreign clubs/leagues, but when international competitive events come, the elite players are recruited to compose a national team. One can expect that the higher ranking of a national team, the more players are employed by the top soccer leagues. However, the relationship between the two issues has never been studied early. In the study, seven national soccer teams were selected from a list of the world top 35 soccer teams of year 2010[created by the Federation of International Football Association (FIFA)]. The 7 teams are Spain, England, Argentina, Germany, USA, Ghana and Sweden, across the full range of the list, thus, representing different levels of the world. On basis of the position of the 7 teams in the world ranking, an order ranking for the 7 teams was created. To identify player distribution of the 7 teams in different quality/level of soccer leagues, a league ranking including the top 25 soccer leagues in the world created by the International Federation of Football History and Statistics (IFFHS) was used. For each of the 7 teams, its player distribution in different soccer leagues was classified. On basis of the league ranking and the number of player(s) of each team in different leagues, calculated team point was calculated for each team. According to the amount of the calculated point, a calculated team ranking was obtained. Correlation analysis was performed between the two rankings: the order ranking and the calculated team ranking. The results showed a high and positive correlation between the two variables. We concluded that the more players are employed in higher ranking leagues the higher world ranking of a national team.
\end{abstract}

Keywords Soccer Game, World Ranking, League Ranking, Player distribution, Correlation Analysis

\section{Introduction}

Soccer game, the most popular sport in the world, has a well-developed system, clubs, leagues and international organizations such as FIFA [1-3]. With the system, professional soccer players could joint different clubs/leagues [4], and when international competitive events come, the top elite players could be recruited to join different national teams. The system guarantees the free trading of professional soccer players among different clubs/leagues, therefore the players have more chances to learn different techniques and tactics, and eventually benefit soccer game development [5].

Apparently, soccer player's level is critical in his employment by different ranking leagues; in general, the higher level of a player the higher possibility that the player could be recruited by a higher ranking soccer league and vice versa. The major criteria in evaluating the level of a soccer player are the performance of the player in national and international competitions[2]. Similarly, an indicator of the quality or ranking of a soccer league is its teams' performance in competitive matches against other leagues[6].Following the criteria, the International Federation of Football History and Statistics (IFFHS) evaluates regularly all soccer leagues in the world through a soccer league ranking system [7]. In 2010, IFFHS announced a league ranking which included 25 top leagues in the world. Similarly[8], the Federation of International Football Association (FIFA)evaluates the quality of all national soccer teams and announce regularly a world ranking, which included 35 national soccer teams in the version of 2010 [9].

In the 2010world ranking and league ranking, most teams and leagues were from Europe, whereas very few were from Africa and Asia. Thus, it seems that the world ranking follows the same trend as the league ranking. However, because international trade of soccer player is very common and more elite players from Africa and Asia are employed by European leagues, the real relationship between world ranking and player distribution among different ranking leagues is still unclear.

In the present study, we selected 7 national teams from the year 2010 world ranking list. The 7 teams are Spain, England, Argentina, Germany, USA, Ghana and Sweden. The 7 teams cover the full range of the world ranking list, thus representing different levels in soccer game. The soccer players of each individual team were classified into different leagues. By calculating the average point of each team on 
basis of player distribution in different ranking leagues, and then analyzing the correlation between world ranking and the calculated team ranking of the 7 teams, the present study aimed to reveal the relationship between world ranking and player league distribution. We wish the results could provide some useful knowledge in soccer system development.

\section{Materials and Methods}

\subsection{World ranking and world ranking-based order ranking}

Table 1. FIFA world ranking of year 2010

\begin{tabular}{|c|c|}
\hline Country & Ranking \\
\hline Spain & 1 \\
\hline Netherland & 2 \\
\hline Brazil & 3 \\
\hline Germany & 4 \\
\hline Argentina & 5 \\
\hline Uruguay & 6 \\
\hline England & 7 \\
\hline Portugal & 8 \\
\hline Egypt & 9 \\
\hline Chile & 10 \\
\hline Italy & 11 \\
\hline Greek & 12 \\
\hline Serbia & 13 \\
\hline Croatia & 14 \\
\hline Paraguay & 15 \\
\hline Russia & 16 \\
\hline Swiss & 17 \\
\hline USA & 18 \\
\hline Slovenia & 19 \\
\hline Australia & 20 \\
\hline France & 21 \\
\hline Norway & 22 \\
\hline Ghana & 23 \\
\hline Ukraine & 24 \\
\hline Mexico & 25 \\
\hline Ivory Coast & 26 \\
\hline Slovakia & 27 \\
\hline Turkey & 28 \\
\hline Denmark & 29 \\
\hline Nigeria & 30 \\
\hline Czech & 31 \\
\hline Japan & 32 \\
\hline Algeria & 33 \\
\hline Gabon & 34 \\
\hline Sweden & 35 \\
\hline
\end{tabular}

Information of world ranking was obtained from FIFA(year 2010; Table 1). According to FIFA's world ranking criteria, the total point of each individual team is calculated mainly based on performance of the team in international competitions in the past four years. The world ranking was created on basis of the total point of each team obtained, i.e. a team with the highest point will be placed on the top whereas a team with the lowest point was listed at the bottom of the ranking. On basis of the FIFA world ranking, an order ranking of the 7 teams included in the study will be created.

\subsection{League ranking and player league distribution-based team point calculation and calculated team ranking}

In order to analyze the correlation between world ranking and player league distribution, we first of all have to evaluate the level of all soccer leagues in the world. Among all available authorized international soccer organizations, IFFHS was the only one providing league ranking information. In the ranking, top 25 soccer leagues over the world were included (year 2010; Table 2). The position of each league in the league ranking was decided by the total point gained by the top five clubs of the league in national and international competitions in the past year. The players in each of the 7 teams will be classified into different soccer leagues. For quantitative analysis, the $1^{\text {st }}$ league in the league ranking will be given 25 points and the following leagues will be given one point less in descent order till the last league in the list with 1 point. The leagues outside the list will be given 0 point. For each individual team, the number of players in each league will be multiplied by the league ranking point. The player league distribution-based points were then summed up as team point. On basis of the amount of team point, a team ranking will be created.

Table 2. IFFHS league ranking of year 2010

\begin{tabular}{cc}
\hline League & ranking \\
\hline Spain & 1 \\
England & 2 \\
Italy & 3 \\
Brazil & 4 \\
Germany & 5 \\
France & 6 \\
Argentina & 7 \\
Portugal & 8 \\
Netherland & 9 \\
Ukraine & 10 \\
Belgium & 11 \\
Mexico & 12 \\
Ecuador & 13 \\
Russia & 14 \\
Greek & 15 \\
Peru & 16 \\
Denmark & 17 \\
Paraguay & 18 \\
Turkey & 19 \\
Chile & 20 \\
Colombia & 21 \\
Switzerland & 22 \\
Egypt & 23 \\
Scotland & 24 \\
Uruguay & 25 \\
$<25$ & \\
\hline
\end{tabular}




\subsection{Correlation Analysis}

To analyze the correlation between world ranking and player league distribution, statistical analysis of nonparametric analysis (Spearman's; JMP 5.0.1 SAS Institute Inc., SAS Campus Drive, Cary, NC, USA) was performed for the order ranking and the team ranking of the 7 teams. Significant meaning was set at $\mathrm{p}$-value $\leq 0.05$.

\section{Results}

\subsection{World ranking-based order ranking}

In the world ranking (Table 1), each of the 7 teams has its ranking position. According to the position number, an order ranking of the 7 teams was made as shown in Table 3.

\subsection{Player league distribution-based team point calculation}

On basis of the IFFHS league ranking 2010, player league distribution-based team point was calculated for each of the 7 teams. The calculation and the results were shown in Table 4. Spain had the highest point of 572 whereas Sweden had the lowest of 300. According to the amount of the point of each team, a calculated team ranking was created as seen in Table 3.

Table 3. World ranking-based order ranking and player league distribution-based team ranking

\begin{tabular}{ccc}
\hline Team & $\begin{array}{c}\text { World ranking position } \\
\text { (Order ranking) }\end{array}$ & $\begin{array}{c}\text { Calculated team point } \\
\text { (team ranking) }\end{array}$ \\
\hline Spain & $1(1)$ & $572(1)$ \\
Germany & $4(2)$ & $483(4)$ \\
Argentina & $5(3)$ & $499(3)$ \\
England & $7(4)$ & $552(2)$ \\
USA & $18(5)$ & $329(6)$ \\
Ghana & $23(6)$ & $340(5)$ \\
Sweden & $35(7)$ & $300(5)$ \\
\hline
\end{tabular}

Table 4. Player league distribution-based team point calculation

\begin{tabular}{|c|c|c|c|c|c|c|c|c|}
\hline \multirow[t]{2}{*}{ League } & \multirow[t]{2}{*}{$\begin{array}{l}\text { Ranking } \\
\text { (Ranking point) }\end{array}$} & \multicolumn{7}{|c|}{$\begin{array}{l}\text { The } 7 \text { teams } \\
\text { (Number of player in the league Ranking point) }\end{array}$} \\
\hline & & Spain & England & Argentina & Germany & USA & Ghana & Sweden \\
\hline Spain & $\begin{array}{c}1 \\
(25)\end{array}$ & $\begin{array}{c}20 \\
(20 \times 25)\end{array}$ & & $\begin{array}{c}3 \\
(3 \times 25)\end{array}$ & & & $\begin{array}{c}1 \\
(1 \times 25)\end{array}$ & \\
\hline England & $\begin{array}{c}2 \\
(24)\end{array}$ & $\begin{array}{c}3 \\
(3 \times 24)\end{array}$ & $\begin{array}{c}23 \\
(23 \times 24)\end{array}$ & $\begin{array}{c}4 \\
(4 \times 24)\end{array}$ & & $\begin{array}{c}7 \\
(7 \times 24)\end{array}$ & $\begin{array}{c}4 \\
(4 \times 24)\end{array}$ & $\begin{array}{c}4 \\
(4 \times 24)\end{array}$ \\
\hline Italy & $\begin{array}{c}3 \\
(23)\end{array}$ & & & $\begin{array}{c}6 \\
(6 \times 23)\end{array}$ & & $\begin{array}{c}1 \\
(1 \times 23)\end{array}$ & $\begin{array}{c}4 \\
(4 \times 23)\end{array}$ & $\begin{array}{c}2 \\
(2 \times 23)\end{array}$ \\
\hline Brazil & $\begin{array}{c}4 \\
(22)\end{array}$ & & & & & & & \\
\hline Germany & $\begin{array}{c}5 \\
(21)\end{array}$ & & & $\begin{array}{c}1 \\
(1 \times 21)\end{array}$ & $\begin{array}{c}23 \\
(23 \times 21)\end{array}$ & $\begin{array}{c}3 \\
(3 \times 21)\end{array}$ & $\begin{array}{c}3 \\
(3 \times 21)\end{array}$ & $\begin{array}{c}1 \\
(1 \times 21)\end{array}$ \\
\hline France & $\begin{array}{c}6 \\
(20)\end{array}$ & & & $\begin{array}{c}1 \\
(1 \times 20)\end{array}$ & & $\begin{array}{c}1 \\
(1 \times 20)\end{array}$ & $\begin{array}{c}2 \\
(2 \times 20)\end{array}$ & $\begin{array}{c}2 \\
(2 \times 20)\end{array}$ \\
\hline Argentina & $\begin{array}{c}7 \\
(19)\end{array}$ & & & $\begin{array}{c}6 \\
(6 \times 19)\end{array}$ & & & & \\
\hline Portugal & $\begin{array}{c}8 \\
(18)\end{array}$ & & & $\begin{array}{c}1 \\
(1 \times 18)\end{array}$ & & & & \\
\hline Netherland & $\begin{array}{c}9 \\
(17)\end{array}$ & & & $\begin{array}{c}1 \\
(1 \times 17)\end{array}$ & & & $\begin{array}{c}1 \\
(1 \times 17)\end{array}$ & $\begin{array}{c}4 \\
(4 \times 17)\end{array}$ \\
\hline Ukraine & $\begin{array}{c}10 \\
(16)\end{array}$ & & & & & & & \\
\hline Belgium & $\begin{array}{c}11 \\
(15)\end{array}$ & & & & & & & \\
\hline Mexico & $\begin{array}{c}12 \\
(14)\end{array}$ & & & & & $\begin{array}{c}2 \\
(2 \times 14)\end{array}$ & & \\
\hline Ecuador & $\begin{array}{c}13 \\
(13)\end{array}$ & & & & & & & \\
\hline Russia & $\begin{array}{c}14 \\
(12)\end{array}$ & & & & & & & \\
\hline Greek & $\begin{array}{c}15 \\
(11)\end{array}$ & & & & & & & $\begin{array}{c}2 \\
(2 \times 11)\end{array}$ \\
\hline
\end{tabular}




\begin{tabular}{|c|c|c|c|c|c|c|c|c|}
\hline Peru & $\begin{array}{c}16 \\
(10)\end{array}$ & & & & & & & \\
\hline Denmark & $\begin{array}{l}17 \\
(9)\end{array}$ & & & & & $\begin{array}{c}1 \\
(1 \times 9)\end{array}$ & & \\
\hline Paraguay & $\begin{array}{l}18 \\
(8)\end{array}$ & & & & & & & \\
\hline Turkey & $\begin{array}{l}19 \\
(7)\end{array}$ & & & & & & & $\begin{array}{c}1 \\
(1 \times 7)\end{array}$ \\
\hline Chile & $\begin{array}{l}20 \\
(6)\end{array}$ & & & & & & & \\
\hline Colombia & $\begin{array}{l}21 \\
(5)\end{array}$ & & & & & & & \\
\hline Switzerland & $\begin{array}{l}22 \\
(4)\end{array}$ & & & & & & $\begin{array}{c}1 \\
(1 \times 4)\end{array}$ & \\
\hline Egypt & $\begin{array}{l}23 \\
(3)\end{array}$ & & & & & & $\begin{array}{c}1 \\
(1 \times 3)\end{array}$ & \\
\hline Scotland & $\begin{array}{l}24 \\
(2)\end{array}$ & & & & & $\begin{array}{c}2 \\
(2 \times 2)\end{array}$ & & \\
\hline Uruguay & $\begin{array}{l}25 \\
(1)\end{array}$ & & & & & & & \\
\hline Others & (0) & & & & & $\begin{array}{c}6 \\
(6 \times 0)\end{array}$ & $\begin{array}{c}6 \\
(6 \times 0)\end{array}$ & $\begin{array}{c}7 \\
(7 \times 0)\end{array}$ \\
\hline Calculated point & & 572 & 552 & 499 & 483 & 329 & 340 & 300 \\
\hline
\end{tabular}

\subsection{Correlation Analysis}

Result of correlation analysis was shown in Figure 1. Correlation coefficient $(r=0.8217)$ was rather high and the $p$ value was 0.0234 .

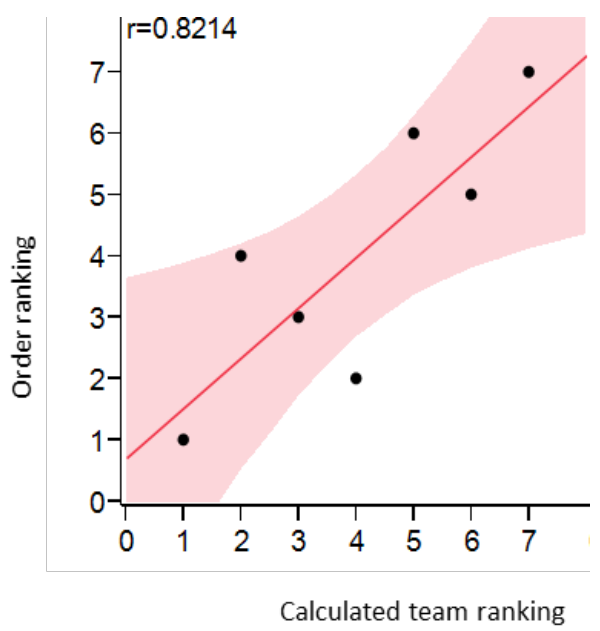

Figure 1. Correlation analysis between the order ranking and the calculated team ranking

\section{Discussion}

\subsection{World ranking and world ranking-based order ranking}

Many factors affect the position of a country in soccer world ranking, including the total amount of soccer players, length of soccer history, population sport enthusiast, economy and importantly, the number of elite soccer players employed by high ranking soccer leagues, according to
Gelade and Dobson[5].

Spain and England had the best and second soccer leagues in 2010, respectively, and most players in the two teams were employed by their home-leagues. However, England league ranking position did not match its world ranking position $\left(7^{\text {th }}\right)$. In the Union of European Football Associations (UEFA) Champion 2008 [10], England was not qualified, and in World Cup 2010, the team was out of quarter final [11]. It has been said that the underperformance of England was due to that most of its elite players were not in lineup in their home-league because of large number of higher level foreign players in the league. However, this on the other side, confirms that the higher ranking of a league, the more foreign players join in [2].

Germany won bronze medal in World Cup 2006 and 2010 $[12,13]$ and silver in UEFA Champion 2008 [14], which contributed to its rather high world ranking $\left(4^{\text {th }}\right)$ and order ranking among the 7 teams $\left(2^{\text {nd }}\right)$. However, on basis of player league distribution, Germany had the $4^{\text {th }}$ position in the calculated team ranking, lower than England of the $2^{\text {nd }}$ position in the calculated team ranking. The lower calculated team ranking of Germany seems mainly to be due to that most its players were in its $5^{\text {th }}$ ranking league [15], much lower than the England league of the $2^{\text {nd }}$ position.

Soccer game is part of the culture in Argentina [16] and is one of the countries in South America with high population of soccer players [17]. This may contribute largely to its $3 \mathrm{rd}$ position in both the world ranking and the calculated team ranking, as well as its $9^{\text {th }}$ position in league ranking.

Swedish had very high interest in soccer game. According to a survey of Sweden Football Association in 2009[18], $47 \%$ Swedish were actively interested in soccer game. However, its team player distribution revealed that most of them were employed by low ranking leagues or leagues out of the top 25. The lower ranking league distribution of elite 
players might be correlated with Sweden's low position in both the world ranking and the order ranking among the 7 teams.

In USA, soccer game was not in the focus of interest for a large population [19]. In world ranking, USA was in position $18^{\text {th }}$ and became the $5^{\text {th }}$ in order ranking among the 7 teams. In our calculated team ranking, USA was $6^{\text {th }}$, right before Sweden. Analysis of player distribution of the two teams revealed that Sweden had more players in leagues out of the top 25 leagues, but less players in high ranking leagues than USA, a result confirmed again that player league distribution is important for world ranking.

Ghana was at $23^{\text {rd }}$ in world ranking and $6^{\text {th }}$ among the 7 teams. The team was in the $8^{\text {th }}$ final in World Cup 2006 and quarter final in UEFA Champion 2010 [12,13]. In Africa Cup of Nations, the team took bronze medal in 2008 and silver medal in 2010 [20,21]. The fact that Ghana exported more players to higher ranking leagues in 2008 [22,23] might contribute to its big advance in World Cup and Africa Cup of Nations 2010. Ghana Football Association was establish rather late (year 1957) [22] compared with most European countries like Germany (year 1900) [24] and England (year 1863) [25]. According to Gelade and Dobson[5], the length of soccer history in a country significantly affects its current soccer level, because both soccer organization system and rules need time to be developed. We could expect that Ghana would catch up European in soccer game in the near future if more elite players are going to be employed by European leagues.

\subsection{League ranking and league ranking-based team ranking}

In the study, the IFFHS league ranking was used, despite the critics that the ranking is a one-man show in soccer league ranking [26]. As shown in the ranking (Table 2), Europe has the most leagues in the ranking and all the first 3 leagues were from Europe. This is consistent with previous study that the best soccer players are in Europe [27-29] and that the European leagues such as England, Spain, Italy and Germany are the best in Champions league [2].

Interestingly, the 4 leagues are very similar in soccer techniques and tactics. However, this is not strange considering that many players were from the same clubs or leagues, and meet often in completion. This will of course give the players many chances to learn from each other.

It is easy to notice in Table 4 that all the players from Spain, Argentina, England and Germany were employed by the top 9 leagues. For England and Germany, all their players were in home leagues, which were the $2^{\text {nd }}$ and $4^{\text {th }}$ in the league ranking, respectively. Similarly, Spain had 20 players in home league. For the 3 teams which had many players in home leagues, they were common in having a well-developed training system for young players. The Premier League is well-known for its young soccer players through Premier Academic League (Barclays Premier League). For example, the England West Ham has trained many talented players and they were sent later to high level soccer clubs of Premier League [30]. In Germany, it is even become compulsory for the best leagues to have young player training stations. Similarly, Barcelona FC also has its own young and world-leading soccer player clubs [31].

Even though the calculated team point of Argentina and Germany are very close to each other (Table 3; 483 vs. 499), player distribution of the two teams are completely different. While Germany had all its players in home league of $5^{\text {th }}$ position in league ranking, Argentina had its players spreading among the top 9 leagues (Table 3).

The leagues of both USA and Sweden were out of the top 25 league ranking list. USA had 4 players in home-league and 15 players in the top 10 leagues. However, none of its players was in the $1^{\text {st }}$ ranking league [32]. Similarly, Sweden had 5 players in home-league and 13 players in the top 10 leagues, and none was in the $1^{\text {st }}$ league [22]. The league of Ghana was also out of the top 25 leagues. However, Ghana had the most players among the 7 teams employed by foreign higher ranking leagues. In 2008, there were 20 team members played outside Ghana in much higher ranking leagues, which might directly correlated with the result that Ghana was the best team in Africa during the time $[33,34]$.

\subsection{Correlation between world ranking and distributions of players among soccer leagues}

Correlation analysis showed a positive and high correlation $(\mathrm{r}=0.8217)$ between world ranking and player league distribution (Figure 1). In studying soccer player trading, Solberg [2] noticed similar relationship between world ranking and player distribution among different ranking leagues. In the study the authors observed that the achievements of both France and Norway were closely correlated with the number of abroad players. In the latest two World Cups, Norway had $68 \%$ and $86 \%$ national team players playing in other soccer leagues. The Greek team also showed high correlation between its achievement and player distribution.

An exception of high correlation between world ranking and player league distribution is England. England had rather high league ranking $\left(2^{\text {nd }}\right)$, but its world ranking was only at position $7^{\text {th }}$. Therefore, other factors need to be considered to affect its team world ranking. A common knowledge is that even in the same league, different clubs have different level. Sometimes, club level variation is much larger than league level variation. That might well explain that most Spanish national team players concentrated in the best two clubs $[34,35]$. Obviously, more studies are needed to further explore the impact of club level on league ranking and even world ranking.

As a preliminary study, we recognized the low number of countries included in the study. On basis of the current results, further study to include more countries, leagues and even some clubs is needed to explore the relationship between player distribution and world ranking. 


\section{Conclusion}

The world ranking is highly correlated with player league distribution. The more players playing in higher ranking leagues, the higher world ranking position of a team could achieve. However, other factors like club level, soccer history, population of sport enthusiast and economy could not be excluded.

\section{Acknowledgements}

We are very grateful to Dr. Christer Malm for help in statistical analysis.

\section{REFERENCES}

[1] B. Milanovica. Globalization and goals: does soccer show the way? Review of International Political Economy, Vol. 12, No. 5, 829-850, 2005.

[2] H. A. Solberg. The international trade of players in European club football: consequences for national teams. International Journal of Sports Marketing \& Sponsorship, Vol. 10, No. 1, 79-93, 2008.

[3] M. Taylor. Global Players? Football, Migration and Globalization, c. 1930-2000. Historical Social Research, Vol. 31, No. 1, 7-30, 2006.

[4] J. Maguirea, R. Peartonb. The impact of elite labour migration on the identification, selection and development of European soccer players. Journal of Sports Sciences, Vol. 18, No. 9, 759-769, 2000

[5] G. A. Gelade, P. Dobson. Predicting the Comparative Strengths of National Football Teams. Social Science Quarterly, V1. 88, No.1, 244-258, 2007.

[6] N. C. Vanyperen, Self-Enhancement Among Major League Soccer Players: The Role of Importance and Ambiguity on Social Comparison Behavior.Journal of Applied Social Psychology,Vol. 22, No. 15, 1186-1198, 2006

[7] The Strongest National League in the World 2010. Online available

from http://www.iffhs.de/index.php?b6e28fa3002f76b55a76917f7 370eff3702bb1c2bb17/

[8] FIFA/Coca-Cola World Ranking Procedure. Online available from

http://www.fifa.com/worldranking/procedureandschedule/m enprocedure/index.html/

[9] FIFA/Coca-Cola World Ranking. Online available from http://www.fifa.com/worldranking/rankingtable/index.html/

[10] UEFA EURO 2008. Online available from http://www.uefa.com/uefaeuro/season=2008/teams/team=39/ matches/index.html

[11] World Cup. Online available from http://nr.soccerway.com/international/world/world-cup/2010 -south-africa/s4770/final-stages/
[12] World Cup. Online available from http://nr.soccerway.com/international/world/world-cup/2006 -germany/s1400/final-stages/

[13] World Cup. Online available from http://nr.soccerway.com/international/world/world-cup/2010 -south-africa/s4770/final-stages/

[14] European Championship. Online available from http://nr.soccerway.com/international/europe/european-cham pionships/2008-austria-switzerland/s1532/final-stages/

[15] B. Frick, G. Pietzner, J Prinz. THE LABOR MARKET FOR SOCCER PLAYERS IN GERMANY. Eastern Economic Journal, Vol. 33, No. 3, 429-441, 2007

[16] A. Noguera. Soccer in Argentina: A Lecture. Journal of Sport History, Vol. 13, No. 2, 147-152, 1986

[17] M. Kunz. 265 million playing football. FIFA magazine, 10-14, July, 2007.Online available from http://www.fifa.com/mm/document/fifafacts/bcoffsurv/emag a_9384_10704.pdf

[18] Sweden Football Association. Online available from http://fogis.se/ImageVault/Images/id 43467/scope_0/Image VaultHandler.aspx

[19] P. Dahlén. Den lilla sporten i det stora landet. Svensk idrottsforskning, Vol. 19, No. 4, 16-19, 2010

[20] Africa Cup of Nations, Online available from http://nr.soccerway.com/international/africa/africa-cup-of-na tions/2008-ghana/s2007/final-stages/

[21] Africa Cup of Nations, Online available from http://nr.soccerway.com/international/africa/africa-cup-of-na tions/2010-angola/s4807/final-stages/

[22] Fotbolls VM 2010. Sveriges trupp. Online available from http:/www.fotbollsvm-2010.se/kvalet/sveriges-kvaltrupp/.

[23] R. Poli. Migrations and Trade of African Football Players: Historic, Geographical and Cultural Aspects. Africa Spectrum, Vol. 41, No. 3, 393-414, 2006

[24] Germany association info. Online available from $\mathrm{http} / /$ www.uefa.com/memberassociations/association=ger/p rofile/index.html/

[25] England association info. Online available from http://www.uefa.com/memberassociations/association=eng/i ndex.html/

[26] E. Eggers. Auf der Suchenach Dr. Alfredo Pöge - Der Nabel des Weltfussballs, Online available from http://www.11 freunde.de/artikel/auf-der-suche-nach-dr-alfre do-poege, Vol. 60, No. 11, 2006

[27] C. Anderson. Comparing the best soccer leagues in the worlda "style of play" statistical breakdown. Sports, Inc, Vol. 3, No. $1,14-17,2010$

[28] B. Frick, THE FOOTBALL PLAYERS' LABOR MARKET: EMPIRICAL EVIDENCE FROM THE MAJOR EUROPEAN LEAGUES. Scottish Journal of Political Economy, Vol. 54, No. 3, 422-446, 2007

[29] P. Millward. Spatial mobilities, football players and the World Cup: evidence from the English premier league. Soccer and society, Viol. 14, No. 1, 20-34, 2012 
[30] The academy of football. British council. Online available from

http://premierskills.britishcouncil.org/sites/premierskills/files /attachment/WestHam_academy_of_football_A4_answers_fi nal.pdf

[31] G. Wahl. The World's Team. Sports Illustrated, Vol. 117, No. 14, 66-74, 2012

[32] FIFA world cup South Africa. Online available from http://www.fifa.com/worldcup/archive/southafrica2010/team s/team=43921/squadlist.html/
[33] P. Darby. 'Go Outside': The History, Economics and Geography of Ghanaian Football Labour Migration. African historical review, Vol. 42, No. 1, 19-41, 2010

[34] 2010 FIFA world cup South Africa. Online available from http://www.fifa.com/worldcup/archive/southafrica2010/team s/team $=43969 /$ squadlist.html/

[35] Liga de FútbolProfesional. Ranking Liga BBVA - Season 2009/2010, 2010. Online available from http://www.lfp.es/Estadisticas/ClasificacionHistoricos.aspx/ 